\title{
INERTIA, UNCERTAINTY, AND CANADIAN HOMICIDE LAW: AN INTRODUCTION TO THE SPECIAL ISSUE
}

\author{
SANJEEV ANAND* AND KENT ROACH ${ }^{* *}$ \\ SPECIAL ISSUE COORDINATORS
}

Ten years ago, a collection of essays written by six leading criminal law scholars from England and Wales was published in a single volume and its editors had lofty aspirations for the book. Entitled Rethinking English Homicide Law, ${ }^{1}$ the manuscript proposed, discussed, and evaluated possible reforms to the English law of homicide. The editors candidly admitted that their aim in publishing the book was to ignite debate on some of the key issues in the law of homicide with the hope that legislative action might ultimately result. ${ }^{2}$

However, the editors were also cognizant that legislative reform would be unlikely to come about purely from the work of academic criminal lawyers. ${ }^{3}$ Optimally, if the publication of the volume coincided closely in time with high-profile events that resulted in public pressure for legislative change, Parliament may be moved to act and the outcome might be legislative enactments that incorporated many of the reform proposals outlined in Rethinking English Homicide Law.

This turn of events is exactly what transpired. As a result of a number of cases, including the killing of an aspiring model by her boyfriend who then successfully raised the defence of provocation, the government eventually ordered the Law Commission to examine the English law of homicide. ${ }^{4}$ In its report published in 2006, ${ }^{5}$ the Law Commission cites directly from Rethinking English Homicide Law as well as from commissioned research by many of the scholars who contributed to Rethinking English Homicide Law. The proposals for legislative reform contained within the Law Commission report called for, among other things, small but important changes to the law of partial defences to murder and massive structural changes to the murder offence itself, including the division of murder into first degree murder with a mandatory life penalty and second degree murder with a discretionary life maximum penalty. ${ }^{6}$

Although the government did follow through with legislation in line with many of the Law Commission's recommendations, it did not enact the major structural changes to the law of homicide urged by the Law Commission. Predictably, the government balked at the proposal

* $\quad$ Professor of Law, University of Alberta.

** Professor of Law, University of Toronto.

1 Andrew Ashworth \& Barry Mitchell, eds., Rethinking English Homicide Law (Oxford: Oxford University Press, 2000).

2 Andrew Ashworth \& Barry Mitchell, "Introduction” in Ashworth \& Mitchell, ibid., 1 at 1-2 ["Introduction"].

Ibid. at 2.

$4 \quad$ Jenny Watson, “Killing Puts Law in Dock” Liverpool Echo (31 October 2003), online: Liverpool Echo $<$ http://www.liverpoolecho.co.uk/liverpool-news/local-news/2003/10/31/killing-puts-law-in-dock100252-13576698/>.

5 U.K., The Law Commission, Murder, Manslaughter and Infanticide (Project 6 of the Ninth Programme of Law Reform: Homicide, Law Com No 304) (London: The Stationery Office, 2006).

$6 \quad$ Ibid. at 172-76. At present, the offence of murder in England and Wales is one crime with one sentence and it is not divided into more and less grave versions or degrees. Murder carries a mandatory minimum punishment of life imprisonment and a person is liable for murder by causing a person's death either with the intent to kill or with the intent to cause grievous bodily harm. 
to eliminate the mandatory life sentence for some offenders who would today be caught by England's murder provisions. Instead, the government opted for changing the law pertaining to the defences of diminished responsibility and provocation.

There are many parallels between the English situation prior to the publication of Rethinking English Homicide Law and the current Canadian situation, but there are also interesting differences in the circumstances found in the two countries. In both nations, there exists significant inertia on the part of the government to reforming homicide laws with virtually no significant legislative action being undertaken in this area for decades. This inertia may be explained, in part, by the relatively rare occurrence of homicides in both countries. ${ }^{8}$ But as eloquently stated by the editors of Rethinking English Homicide Law,

the relative rarity of ... homicides should not be used as an excuse for ignoring the need to reform the law.

Some have argued that criminal homicide is a unique form of offending in so far as it represents a wrong done against a "higher authority." Whatever view one takes of this, homicide has a strong claim to be (at least) one of the most serious crimes.... The need for the criminal justice system to respond to its most heinous offences in a principled and rational manner is unaffected by the volume of offences. ${ }^{9}$

There are also some distinguishing features. In Canada, the Supreme Court has significantly reformed the law of homicide by invalidating various constructive murder provisions as well as the objective arm of unlawful act object murder under s. 229(c) of the Criminal Code. ${ }^{10}$ In addition, Canada no longer has a Law Commission that can assist Parliament in providing research and principled and non-partisan arguments for law reform. Moreover, the Canadian Parliament has been active in expanding first degree murder in perhaps unnecessary responses to a series of highly publicized crimes. ${ }^{11}$ At the same time, the criminal justice systems of both England and Canada still do not respond to homicide offences in a principled and rational manner. Indeed, there exists a great deal of uncertainty in the homicide laws of both countries. This is striking in view of the seriousness of the offences and the need in both nations for judges to be able to explain the law of homicide to juries.

The collection of essays contained within this special issue of the Alberta Law Review, entitled Rethinking Canadian Homicide Law, exposes some of the uncertainties in Canadian homicide law. Moreover, it is hoped that the articles written by five Canadian criminal law

See Coroners and Justice Act 2009 (U.K.), 2009, c. 25.

In 2007, the homicide rate was approximately 1.3 homicides per 100,000 population in England and Wales, whereas in Canada the homicide rate was approximately 1.8 homicides per 100,000 population: see Geoffrey Li, "Homicide in Canada, 2007” (2008) 28:9 Juristat 1 at 6-7.

$9 \quad$ "Introduction," supra note 2 at 3 [footnotes omitted].

10 R.S.C. 1985, c. C-46, s. 229(c). See R. v. Vaillancourt, [1987] 2 S.C.R. 636; R. v. Martineau, [1990] 2 S.C.R. 633 [Martineau]; R. v. Sit, [1991] 3 S.C.R. 124.

11 See Criminal Code, ibid., s. 231(6), deeming murder committed during criminal harassment to be first degree murder; s. 231(6.01), deeming murder committing during a terrorist activity to be first degree murder; s. 231(6.1), deeming murder committed during explosives and criminal organizations offences to be first degree murder; s. 231(6.2), deeming murder committed during the intimidation of a justice system participant to be a first degree murder. In many of these cases, the murders would already be first degree murders because they would be planned and deliberate murders. A possible exception might be murders committed during "stalkings" or acts of criminal harassment. Nevertheless, one article in this collection suggests that the amendment in s. 231(6) has only been used once in a sample of 250 reported cases: see Isabel Grant, "Intimate Femicide: A Study of Sentencing Trends for Men Who Kill Their Intimate Partners” (2010) 47 Alta. L. Rev. 779 at 787. 
scholars may have a similar effect on legislative reform in this country as Rethinking English Homicide Law did in England. As in England, the legislative reform of the law of homicide is unlikely to be achieved through the work of academics alone. High-profile cases that point out the deficiencies in the law of homicide will, as in England, constitute important catalysts for reforming the law. However, many of those high-profile cases are currently before Canadian courts. For example, the ongoing litigation surrounding the Boxing Day killing of Jane Creba in Toronto ${ }^{12}$ and the Katerina Effert murder appeal in Alberta concerning the death of Effert's newborn son ${ }^{13}$ have captured the public's attention and aroused passionate debate. Thus, it may be an opportune time for the publication of a series of articles on Canadian homicide law.

All of the articles in this special issue share a number of features in common. Every article either urges legislative reform to address the ambiguities that exist in Canadian homicide law or demonstrates the efficacy with which legislative reform can change problematic judicial attitudes in this area of the law.

In addition, all of the writers that call for the legislative reform of the Canadian law of homicide seem to be implicitly cognizant of the political realities surrounding the reform process. A public opinion poll conducted in the United States, Britain, and Canada revealed that a majority of respondents in all three countries support mandatory minimum sentences and particularly harsh penalties for murder. ${ }^{14}$ In a recent interview, Geneviève Breton, the Director of Communications for the Canadian federal Justice Minister Rob Nicholson, noted that the Conservative government has added to the list of criminal offences that carry a mandatory minimum sentence and she suggested that, in doing so, the government was responding to public pressure. Specifically, she stated:

Parliament is expected to draft and enact laws that clearly articulate the legislators' intent, which is reflective of the values of the citizens who elected them. It is the role of the legislator to give guidance to the judiciary on maximum penalties, as well as on minimum penalties. For certain offences, our Government firmly believes that a minimum period of incarceration is justified. ${ }^{15}$

Against this background, it is understandable why Professor Wayne Renke's discussion of the defence of provocation and Professor Sanjeev Anand's examination of the offence/defence of infanticide rest implicitly on the assumption that Canadian lawmakers, like their English counterparts, would be unwilling to abolish the mandatory minimum

12 This case is discussed in Kent Roach, "The Problematic Revival of Murder Under Section 229(c) of the Criminal Code” (2010) 47 Alta. L. Rev. 675.

13 This case is discussed in Sanjeev Anand, "Rationalizing Infanticide: A Medico-Legal Assessment of the Criminal Code’s Child Homicide Offence” (2010) 47 Alta. L. Rev. 705.

14 "Americans, Britons and Canadians Take Harsh Stance on Crime” Angus Reid Public Opinion (22 January 2010), online: Vision Critical <http://www.visioncritical.org/wp-content/uploads/2010/01/ 2010.01.22_Crime.pdf $>$; Kirk Makin, “Canadians' Views on Crime are Hardening, Poll Finds” The Globe and Mail (21 January 2010), online: The Globe and Mail <http://www.theglobeandmail.com/ news/national/canadians-views-on-crime-are-hardening-poll-finds/article1439726>. For a discussion of earlier public opinion surveys taken of Canadian attitudes towards mandatory minimum sentences, see Julian V. Roberts, Nicole Crutcher \& Paul Verbrugge, "Public Attitudes to Sentencing in Canada: Exploring Recent Findings” (2007) 49 Canadian Journal of Criminology and Criminal Justice 75.

15 Harris Macleod, “Justice Minister Nicholson Pushes Crime Bill He Used to be Against” The Hill Times (1 February 2010), online: The Hill Times <http://www.thehilltimes.ca/page/view/justice-02-01-2010>. 
sentence of life imprisonment for any form of murder. ${ }^{16}$ Likewise, Professor Kent Roach suggests that the remaining unlawful object murder provision in the Criminal Code could usefully be repealed or at least be amended to reform its unconstitutional negligence arms, but he is not optimistic that such reforms will occur. Instead, he focuses on clarifying the fault element in this offence.

In his article on the law of manslaughter, Professor Larry Wilson argues that although the Supreme Court has recently clarified certain issues surrounding this offence, there remains much that needs to be resolved by Parliament. For example, Wilson notes that in Beatty ${ }^{17}$ and J.F. ${ }^{18}$ the Supreme Court has addressed the redundancy between the many manslaughter provisions in the Criminal Code and the need to define a clear separation between the actus reus and mens rea for various forms of manslaughter. Following the approach outlined in these cases, the actus reus for one form of manslaughter, criminal negligence causing death, should be defined by the statutory language, that is, proof that the accused has done something or failed to do something for which he had a legal duty and that resulted in death and that shows a wanton and reckless disregard for the lives and safety of others. Professor Wilson contends that, in future cases, courts will face significant difficulties trying to distinguish between conduct that may or may not satisfy the actus reus of the offence, namely wanton and reckless disregard, and conduct that may or may not satisfy the mens rea of the offence, namely a marked and substantial departure from the conduct of a reasonably prudent person in the circumstances. In other words, in practice there may continue to be a lack of separation between the approach to the various elements of criminal negligence offences and there remains uncertainty as to the meaning to be ascribed to the words "wanton and reckless" in the context of those offences. ${ }^{19}$ Wilson observes that the Supreme Court in J.F. has established distinct categories of objective fault for different types of manslaughter offences. The Court clearly states that the fault element for criminal negligence causing death is a marked and substantial departure from the conduct of the reasonable person whereas manslaughter committed by way of a failure to provide the necessaries of life has a lower fault requirement of a marked departure from the standard of the reasonable person. In essence, the Supreme Court has endorsed a marked departure test for crimes of penal negligence and a marked and substantial departure test for crimes of criminal negligence. But Wilson also points out that this new normative distinction between degrees of gross negligence is likely to confuse lawyers, judges, and jurors. Finally, he recognizes that Beatty establishes that the minimum constitutional fault standard for criminal offences resulting in imprisonment is a marked departure from the objective norm. As a result, Wilson argues that

The unlikelihood of the Canadian Parliament abandoning the mandatory life sentence for any form of murder has been asserted by numerous commentators: see e.g. Winifred Holland, "Murder and Related Issues: An Analysis of the Law in Canada" in Jeremy Horder, ed., Homicide Law in Comparative Perspective (Oxford: Hart, 2007) 107 at 131. For a slightly more optimistic appraisal of the prospect of amending the sentence for second degree murder from a mandatory minimum of life imprisonment to a maximum of life imprisonment, see Steve Coughlan, "Reforming Homicide Law to Separate Guilt from Sentence: An International Gloss” (2008) 13 Can. Crim. L. Rev. 1.

R. v. Beatty, 2008 SCC 5, [2008] 1 S.C.R. 49 [Beatty].

R. v. J.F., 2008 SCC 60, [2008] 3 S.C.R. 215 [J.F.].

For a post-Beatty and J.F. case that attempts to give clear meaning to the phrase "wanton and reckless" in the context of a charge of criminal negligence causing death, see R. v. Tayfel, 2009 MBCA 124, 245 Man. R. (2d) 300. In this case, the Manitoba Court of Appeal found that the accused's conduct constituted a marked and substantial departure from the standard of a reasonable and prudent pilot but that the evidence did not establish that the accused showed a wanton or reckless disregard for the lives and safety of others. Consequently, Tayfel's convictions for criminal negligence causing death and bodily harm were set aside. 
it is no longer sufficient for the Crown to merely prove the fault requirement for the unlawful act and reasonable foresight of bodily harm in the context of an unlawful act manslaughter prosecution. Yet it can be contended that the combined fault requirements of the unlawful act and reasonable foresight of bodily harm constitute a level of blameworthiness that is at least equivalent to and as onerous to prove as the standard represented by the marked departure standard. Consequently, it may be that the Crown will not be required to prove, as a constitutional imperative, that the accused's conduct constituted a marked departure from the standard of the reasonable person in every unlawful act manslaughter case. Clearly, however, this remains an area of ambiguity that, along with the others mentioned by Professor Wilson, could best be resolved through legislation.

Professor Roach's article on unlawful object murder demonstrates that the legislative inertia surrounding the murder provisions in the Criminal Code has led to cases in which murder convictions have been overturned and new trials ordered because trial judges have left juries with versions of s. 229(c) that still include a negligence arm that was declared to be unconstitutional by the Supreme Court in $1990 .{ }^{20}$ Three unfortunate cases are examined where trial judges erred by leaving the jury a copy of s. 229(c) with its unconstitutional objective arm present. In his article, Roach examines the increased use of the murder offence under s. 229(c) of the Criminal Code including in cases stemming from the Boxing Day shooting of Jane Creba. Professor Roach maintains that unless s. 229(c) is judged to only be applicable in situations were the offender has an unlawful object that is distinct from the actions that killed the victim, s. 229(c) may eclipse the other forms of murder in s. 229. It is also argued that the statutory requirement of subjective knowledge of the likelihood of death means that s. 229(c) requires that an offender be cognizant of the probability that his or her actions may result in the death of a person. Roach notes that the Ontario Court of Appeal in a series of cases has stressed that the subjective knowledge of the likelihood of death requirement in s. 229 is not satisfied by proof that an accused was cognizant merely of the risk or chance of death occurring. ${ }^{21}$ However, the Ontario Court of Appeal also did not find the following charge to the jury on the definition of "likely" in the context of s. 229 to constitute reversible error:

Likely means more than a possibility. It involves a substantial degree of probability. However, it does not mean more likely than not in the mathematical sense of 51 percent. The phrase is meant to convey the notion of a substantial or real chance, as distinct from a mere possibility. Likely to cause death means could well cause death. A fine calculation that the odds were against death, although the risk was plainly there, is no defence. By using the word "likely" the legislators were trying to get at killings where the risk was subjectively so appreciable that to engage in the conduct would be seen as a virtual equivalent of an intentional killing. A likelihood is a real risk, a substantial risk or something that might well happen. ${ }^{22}$

Where "likely" stands on the spectrum from possible to probable should be clarified by Parliament. (C.A.).

R. v. Edelenbos (2004), 71 O.R. (3d) 698 at para. 14 (C.A.). 
Although it is a cornerstone of both the statutory and constitutional interpretation of the law of murder, the actual meaning of subjective knowledge of death is underdeveloped. Professor Roach points out that the Supreme Court has described the constitutional fault for murder to be subjective foresight of death and has not clearly indicated the degree of subjective foresight that is required. Nevertheless, he argues that Canadian courts should not recognize reckless murder as a constitutional form of the offence.

Professor Roach warns that the increased use of s. 229(c) has resulted in a de facto form of constructive murder based on notions of objective fault and that the revived use of s. 229(c) violates the principle of fundamental justice that non-intentional harm should not be punished as harshly as intentional harm. He recounts a case resulting in a conviction under s. 229(c) in which a trial judge moved rather quickly from the common sense proposition that a reasonable person would and should have recognized foreseeability of death when pursuing dangerous unlawful objects to a conclusion that the accused in fact did foresee such harm even though he had no intent to hurt anyone. In order to avoid the de facto diluting of the constitutionally required subjective fault for murder, Roach contends that prosecutors seeking a conviction under s. 229(c) should establish that the accused's subjective knowledge of the probability of death related to a group of determinate victims, including the actual victim. In addition, the guilty knowledge of the likelihood of death must be present at the time of the accused's acts that actually caused the victim's death. Finally, courts should recognize that the ambit of what remains of s. 229(c) is restrained by a principle of fundamental justice that a person, even a criminal who is pursuing an unlawful object, should not be convicted of murder for an accidental death.

Professor Anand's article on infanticide outlines a number of unclear aspects concerning the offence/defence and he makes suggestions about the proper interpretation of the infanticide provisions by resorting to a number of means, including the legislative history of the provisions. A review of this legislative history indicates that the biological rationale for the offence/defence was never scientifically established or in vogue, but that the real reason for enacting the offence/defence was to achieve more appropriate outcomes for homicide litigation directed at new mothers. Anand provides rationales for his interpretations of key words and phrases in the infanticide offence, such as the meaning of the phrase "mind is then disturbed. ${ }^{23} \mathrm{He}$ also attempts to resolve other ambiguities surrounding the infanticide laws, including the fault requirement of the offence and the burden of proof associated with raising the infanticide defence to a charge of murder.

The medical rationale explicitly underpinning the infanticide provisions is assessed against the background of contemporary medical knowledge with some surprising results. Contemporary medical knowledge concerning postpartum mood and mental disorders suggests that these conditions occur sometime after the first 24 hours following birth. Consequently, Professor Anand asserts that women accused of neonaticides do not properly fall within the scope of the infanticide provision. Moreover, there exists no hard evidence that the physiological changes that accompany childbirth and lactation are implicated in causing mental disturbances in new mothers. In fact, the principal contributors to postnatal mental illness seem to be associated with the stress of child rearing rather than the biology 
of childbirth and/or lactation. If the stresses of child rearing are primarily responsible for causing mental disturbances in those charged with being primary caregivers of young children, Anand concludes that there is no reason to limit the offence/defence of infanticide to biological mothers. Indeed, he asserts that what the infanticide provisions really amount to is a legislative means of addressing a class of offenders whose acts of homicide can, at least partially, be attributed to their mental illnesses. Parliament is urged to expand the class of offenders that are deemed to warrant more lenient treatment not through an expansion of the scope of the infanticide provisions, but through the legislative recognition of a more generally applicable defence of diminished responsibility.

Professor Renke tackles the subject of provocation head-on by noting that there have been calls for the repeal of the controversial partial defence for condoning and privileging homicidal and often male rage. He also notes that there is no psychological evidence supporting the defence. Nevertheless, Renke defends the provocation defence based in part on its 400-year history and the idea that those who kill in a rage and in response to sudden acts or insults and while their powers of self-control are diminished have a reduced form of culpability. Traditionally, provocation served as a means to avoid the mandatory death penalty that used to accompany murder convictions. The death penalty is, of course, gone but Professor Renke argues that the defence still serves an important purpose in avoiding the mandatory sentence of life imprisonment for murder. His article demonstrates the Parliamentary inertia or perhaps stability that has affected this area by comparing the relatively minor changes that have been made since provocation was introduced into the Criminal Code, $1892 .^{24}$

Renke then engages in a detailed analysis of the multiple elements of the provocation defence and makes specific proposals for Parliamentary reform and updating. He warns, however, that Parliament should not impose categorical and perhaps overbroad restrictions on the defence. Professor Renke criticizes the Supreme Court's leading decision in Thibert ${ }^{25}$ for not paying enough attention to the statutory requirements under s. 232(2) that the accused must act "on the sudden and before there was time for his passion to cool." ${ }^{26} \mathrm{He}$ also examines the difficulties of applying the ordinary person in that section and usefully suggests that judges should instruct jurors about what characteristics should and should not be considered when applying that objective test. Renke argues that provocation claims that are based on the aggravating sentencing factors of hate crimes, spousal abuse, and abuse of positions of authority, as well as on values rejected by ordinary Canadians, should be rejected. The latter argument finds support in the Ontario Court of Appeal's decision in $R$. $v$. Humaid ${ }^{27}$ while the former argument is a novel one that usefully draws a link between substantive and sentencing law.

The final article in this special issue, by Professor Isabel Grant, also makes a connection between substantive law and sentencing law by examining sentencing trends for men who kill their intimate partners. She argues that male killings of their partners are distinct from female killings of their partners because the former are motivated by jealousy and 
possessiveness. Although each case has its “own unique mix of brutality and loss," ${ }^{28}$ Grant is struck by the similarities of the more than 250 cases she read. They often involve an offender who has been drinking, suspects the victim of infidelity, and "overkills" in a brutal manner. This important article can be seen as a contribution to a law in action approach by its focus on what actually happens in one category of homicide cases. The article also provides new and significant evidence that courts have been relatively cautious about applying both the provocation and intoxication defences to male killings of intimate partners despite the concerns of many that cases such as Thibert on provocation and the intoxication defence might condone male violence towards women. Provocation and intoxication were not raised in the vast majority of the cases in Professor Grant's sample. Moreover, provocation was only successful in 19 percent of the cases in which it was raised and intoxication was only successful in 13 percent of the cases in which it was raised. The intoxication defence, of course, could not under s. 33.1, enacted in response to the Court's controversial decision in $R$. $v$. Daviault, ${ }^{29}$ be raised as a defence to manslaughter or other general intent offences that interfere with bodily integrity.

Grant examines 252 cases over an 18-year period and finds that whether the offender is convicted of murder, with its mandatory sentence, or manslaughter is the key determinant in sentencing. She finds that planning and deliberation under s. 231(2) is by far the most frequent basis for the 44 first degree murder cases she examines with only one case involving criminal harassment under s. 231(6). This suggests that one of Parliament's additions to the law of homicide may have had little effect on the ground. She observes a trend since Parliament, in 1996, specifically listed abuse of a spouse or a common-law partner as an aggravating feature in sentencing in s. 718.2(a)(ii) of higher sentences for men who killed their intimate partners. From 1990 to 1996, the average manslaughter sentence in her sample was 7.1 years whereas in 2002 to 2008, the average sentence was 10.6 years. Although Professor Grant is careful to note the difficulties of determining cause and effect, this pattern seems to suggest that Parliament may have had some success in countering judicial attitudes that saw male killings of intimate partners as less serious than other forms of homicide. It, of course, remains to be seen whether Parliament will be encouraged by the apparent success of this initiative to be more active in the future in reforming our uncertain but certainly important laws of homicide.

It is certainly possible that Parliament will engage in homicide law reform. If Parliament has time to add to first degree murder, it should have the time to revisit more fundamental issues concerning our unclear basic offences of murder, manslaughter, and infanticide as well as the defence of provocation and sentencing for homicide offences. It is hoped that the articles in this special issue will provide some assistance to both Parliament and the courts as they struggle with the many ambiguities and anachronisms that unfortunately pervade our homicide laws. 